\title{
Field Production of Cut Flowers
}

\author{
John W. Kelly \\ Department of Horticulture, Clemson University, Clemson, SC 29634-0375
}

There has been a recent resurgence of interest in the production of specialty, field-grown cut flowers. While field production of cut flowers is considered to be the development of a new cropping system by some, in reality it is a long-established practice. White (1915) stated in his floriculture textbook: "Previous to 1870 the flower growing business consisted principally of plants for outdoor bedding and for other ornamental purposes. The cut flowers of that period were mostly small-flowered and short-stemmed, such as heliotrope, camellia, tuberose and bouvardia." Much of the current interest is in production and harvesting of plants previously grown as garden annuals and perennials; however, similar interest also occurred early in this century. White (1915) noted: "There is increasing interest among flower growers in annuals and herbaceous perennials which may be forced for cut flowers." A list of recommended annuals and herbaceous perennials for cut flowers was published by Taylor (1916).

There are several factors that limited field production of cut flowers in the United States. White (1915) states: "Greenhouses for the production of flowers are becoming more and more in demand in the south and west, while in many sections climatic conditions are such that cut flowers may be grown out-of-doors; still, the perfection of blooms, due to the better cultural conditions made possible under glass, and the consequent increased financial returns have encouraged growers to erect glass structures." In 1930, more than four times the hectarage was devoted to field culture of cut crops than to greenhouse culture (U.S. Census Bureau, 1931). However, the average receipts per hectare for greenhouse-grown cut flowers were 40 times higher than those for field-grown material, although the cost of greenhouse production probably also was higher.

Laurie and Ries (1950) published additional comprehensive lists of suggested herbaceous perennials for cut flower production, as well as lists of berry-bearing shrubs for cutting, flowering stems for cutting and forcing, and stems with colored bark for cutting. More recently, several extensive lists have been published on recommended plants for commercial field production of cut flowers (Seals, 1988), cut ornamental grasses (Meyer, 1988), cut grains (Godwin, 1988), cut wildflowers and weeds (Weiler, 1988), bulb crops (DeHertogh, 1989; Armitage, 1989) and woody plants (Dirr, 1989).

In recent years, imports have seriously affected U.S. greenhouse production of cut flowers, the reduction changing from $>50 \%$ of the total floriculture market in 1970 to $<20 \%$ in 1987. Two specific markets have been exploited by foreign producers: Dutch growers have captured significant U.S. market share by producing a wide selection of nontraditional cut crops, while the South Americans have captured substantial market share of the traditional florist's crops (carnations, roses, and chyrsanthemums). The Dutch have gained market share by using cooperatives and extensive marketing programs. Several South American countries have a year-round climate well suited for production of several crops and much lower labor and overhead costs than U.S. producers.

Mass marketers have gained a significant share of the U.S. retail cut flower sales, with Kroger now being the largest retail florist in the United States. The Kiplinger Agriculture Letter (1988) stated that "cut flowers and potted plants generated $\$ 28$ per square foot per year $\left(\$ 301 / \mathrm{m}^{2}\right)$ in a supermarket, about twice that generated by fresh produce." The market size and profit potential have led numerous entrepreneurs to attempt to find a profitable cut flower production and marketing system. In addition, many farmers are seeking ways to diversify their operations and improve profit margins. The predominant idea is that specialty annual and herbaceous perennial crops could be profitably grown in the field, avoiding the high overhead cost of operating a greenhouse.
There are many species currently being field-grown with success across the United States for harvest as cut flowers. Some of the more popular and successful crops being produced are Dendranthema, Liatris, Gypsophila, Limonium, and Gladiolus. California and Florida have traditionally been the largest suppliers of fieldgrown cut flowers. Tjia (1985) stated that, in Florida, "new fieldgrown cut flowers such as gerberas, snapdragons, tuberoses, Asiatic hybrid lilies, Dutch iris, and calla lily are replacing more traditional field cut flowers such as spray carnations and chrysanthemums."

There are several critical factors that producers must address to determine their suitability to enter this market.

\section{Costs of production}

To determine the capital investment required and the potential for profit, a crop budget must be developed. In addition, most lending agencies require a crop budget before they are willing to consider financing the venture. Unfortunately, when trying to introduce a "new" crop to the distribution channels, little is known about market acceptance and price for the crop. Brumfield (1989) has developed general budgets for several sizes of field-cut flower operations. Potential for profitability depends on the price that can be obtained for the product. Prices for cut flowers vary considerably during the year and generally peak around major holidays.

\section{Site selection}

The primary reasons that cut flower production shifted to protected cultivation were that higher quality flowers could be produced under glass, weather-related losses from hail and other storms were greatly reduced, and year-round production was possible. Most plants suitable for cut flower production must have long stems to meet market demand; therefore, one of the key considerations in cut flower site selection is protection from wind. In addition to toppling plants, high winds can dessicate leaves or flowers, rendering them unmarketable.

One of the prime market seasons for cut flowers is in early spring. To meet this market demand and obtain high prices for their crops, field producers may attempt to establish transplants before their location is free from frost. Vegetable crop producers have successfully used row covers to increase early yield, and cut-flower producers may also benefit from this production strategy. If this early market is to be met, the producer must select a site that does not have low-lying frost pockets. Unexpected freezes have severely injured field-cut flower crops in California and Florida.

Many other factors that are essential site selection criteria for other crops, such as vegetables, are also critical for cut-flower production. These include availability of suitable quantity and quality of irrigation water, proper soil type and drainage for the species to be grown, and reasonable proximity to marketing or distribution channels.

\section{Labor availability}

Labor requirements for field-grown cut flower producers tend to be highly seasonal, with peaks being during planting and harvest seasons. Problems may arise during harvest when unskilled laborers are not adequately trained to understand quality and proper stage of development for harvest.

Some species flower continuously during the growing season while others flower only for a very short time. This fluctuation may create problems in labor requirements because it becomes difficult to harvest a variety of crops at the correct stage of development. 


\section{Production information}

There is limited production information available for nontraditional field-grown cut flowers, although recent research has begun to focus more on field-grown cut flower crops. In the past, there was a great demand in the United States for greenhouse cut-flower research, particularly on the major crops, such as carnations, roses, and chrysanthemums. Foreign competition has forced many greenhouse operations to switch to pot plant culture, and, consequently, much floriculture research in the United States is now conducted on potted crops. As the need for field-cut flower research becomes more evident, it is likely that increased emphasis will be given to these crops. Armitage (1987) determined optimal spacing for five field-grown cut flower species. He collected yield data for 2 to 3 years and found that, in all instances, the number of flowering stems per square meter decreased as spacing increased. Dufault et al. (1990a, 1990b) outlined nutritional and spacing effects on production of field-grown gerbera cut flowers. Tjia (1985) developed production information for production of calla lily in Florida.

Little is known about pesticide use on field-grown cut flowers. Researchers have rarely addressed the effects of pesticides on yields and flower longevity. Gilreath (1986) investigated the response of three popular field-grown cut flower species to several herbicides and found variable results between 2 years of data collection. $\mathrm{He}$ attributed the variability to rainfall differences between the 2 years. To date, few chemicals are specifically labeled for use on fieldgrown cut flowers. Weed, insect, and disease problems in field-cut flowers have been addressed by Senesac (1988), Ascerno (1988), and Pfleger (1988), respectively, while Rugen (1989) discussed integrated pest management strategies.

Fortunately, recent national conferences have published proceedings with suggestions on production practices. The Commercial Field Production of Cut and Dried Flowers Proceedings and the Proceedings of National Conference on Specialty Cut Flowers are excellent reference materials for producers and researchers. In addition, the Assn. of Specialty Cut Flower Growers offers a quarterly newsletter on field-cut flower production.

\section{Grower experimentation}

Unfortunately, with little university-based research, growers have been forced to invest in research programs of their own, leading to unintentional testing redundancy of certain species. Few growers are properly trained in experimental design and data collection; therefore, much becomes written about a crop without a scientific basis for the conclusions. In addition, some growers are, understandably, reluctant to share the results of their testing efforts with other producers. All of this leads to much duplication of effort.

\section{Species diversity}

The enormous diversity of crops with potential as field-grown cut flowers has advantages and disadvantages to producers. Often, too many choices can impair initial adoption of any one species to grow. Also, while researchers may be able to study a new vegetable or fruit crop in great detail, studying hundreds of new floral crops is not feasible. Too many crops may lead to diluted research or superficial data accumulation, insufficient to improve the knowledge base.

However, the diversity of crops also creates great opportunity, because it gives the producer an opportunity to find an unfilled market niche. If the producer finds a successful crop, several seasons of high demand may be reaped before competitors enter the market with the same product.

Dutch imports of nontraditional cut flowers may actually help U.S. field-cut flower producers because several species that are marketed by the Dutch can be field cultivated in the United States. Wholesalers and retailers have been made aware of these cut flowers by Dutch marketing.

While there is great diversity, there are relatively few cultivars that have been selected for field-cut flower performance by breeders. Much of the breeding for cut-flower production has been done for greenhouse environments. Most improved cultivars of specialty annuals and herbaceous perennials have been selected for improved performance in a cell pack or garden. Selection of plants for stem length, stem strength, earliness to flower, pest resistance, heat tolerance, and postharvest longevity would be of great benefit to fieldcut flower producers. Cultural conditions can alter stem length of certain species. Achillea 'Coronation Gold', A. millefolium 'Rose Beauty', and Physostegia virginiana stem lengths were affected by crop spacing, but flower size and stem diameter remained unchanged (Armitage, 1987).

\section{Harvest and postharvest information}

The cut-flower industry has advanced significantly because of improved postharvest handling of cut flowers. To maximize flower longevity of a cut flower, several criteria must be addressed by researchers and growers. All of the efforts put into producing a high quality crop can be negated by improper postharvest handling at any one stage. In addition, a crop with great potential as a cut flower can fail to reach that potential if a reasonable vaselife is not obtained by the consumer. Cut flowers must be harvested at the correct stage of development. Harvesting prematurely may prevent subsequent bud opening, while harvesting too late may reduce vaselife and increase the chances of damage from ethylene and mechanical injury.

Cut flowers must be properly graded to insure that only high quality flowers are sent to the market. This grading for uniformity needs to agree with market demand. The field producer of newer cut flower crops must often guess how to bunch the flowers after grading; should they be sold in units of 10 or 25 to meet the market demand?

Beneficial postharvest chemical treatments must be determined for each crop to maximize flower longevity, including recommendations for floral preservative use and whether there are any benefits to be derived from using bud opening solutions or anti-ethylene agents.

Furthermore, what temperatures facilitate successful storage? This knowledge will allow producers to target market windows for peak sales. Efficient packing and boxing systems for different species need to be researched.

Perhaps most important, a crop needs to be thoroughly investigated to determine its potential vaselife if properly handled. This information would be of great benefit to everyone associated with handling the product. It would seem vaselife ought to be the first criterion considered when determining whether a new cut-flower crop should be planted for production. If the crop does not last long enough to be of perceived benefit to the consumer, it may never become an important item in the market. It must be recognized, however, that some crops, such as roses, are perceived to be worthy of high prices without having exceptional vaselife. Kelly and Starman (1990) determined proper harvest stage, storage effects, ethylene effect, and optimal preservation concentrations for field-grown Physostegia purpurea cut flowers. Dufault et al. (1990b) developed postharvest information on field-grown Gerbera as a function of plant nutrition and spacing during production. Investigations of postharvest handling techniques have been conducted for several other field-grown cut species including dahlia (Lukaszewska, 1980), calla lily (Tjia, 1985), and liatris (Borochov and Keren-Paz, 1984).

\section{Marketing the products}

Field-grown cut flowers are marketed through the same distribution chain as those grown in the greenhouse, but the outlet market depends on the individual production operation. Potential market outlets are floral wholesalers, supermarket distribution centers, direct sales to supermarkets, retail florists, direct retail, and pickyour-own retail. Sales to floral wholesalers and supermarket distribution centers are generally at lower prices and require a relatively high volume. Some operators attempt to make direct delivery to retailers, but while direct delivery generally brings a higher per unit price, it can also be extremely time consuming. Also, it is unlikely that a producer will be able to sell directly to retailers and also to wholesalers in the area. Some roadside stands and pick-your-own operations have added cut flowers to their product line. 
Marketing specialty field-grown cut flowers can be difficult. The producer is attempting to introduce a relatively unknown product in a market where demand is often dictated by a holiday or special occasions such as weddings or funerals. In this market, the demand shifts rapidly and selling prices fluctuate accordingly. In addition, the product is extremely perishable and there is a limited secondary market (i.e., drying the flowers). Also, it is difficult to guarantee buyers specific quantities and harvest times.

When a new crop is successfully developed, opportunity for market domination is limited because local markets are easily saturated by small hectarage increases in production of the crop. Another problem arises when an excessive supply of major crops such as carnations, roses, or mums exists on the market at low prices. These products are easily picked up by wholesalers in lieu of specialty crops.

\section{Competition}

Competition is very likely to increase in the future for the fieldcut flower producer. Currently, there are market niches that a small producer can fill and allow reasonable profitability for the enterprise. However, entry into the market is relatively easy for any field crop producer in the market area by simple diversification of their operation. Also, as field-cut flower operations grow, they are forced to seek markets outside of their local area. As their market expands, it will impinge on local growers and eventually production will favor those areas with distinct seasonal advantages, and filling market windows will become more critical. California and Florida have had field-grown cut flower operations for many years because of climatic advantages.

Another concern for field producers is that a change in the value of the dollar may favor imported specialty items. Also, many of the same crops being field-produced in the United States could be produced by foreign growers after the market for the particular crop is developed.

Despite the cautions, there seem to be many opportunities. This potential is best shown by data suggesting that U.S. consumers currently purchase about half as many flowers as their European counterparts. As Americans become more frequent purchasers of cut flowers, specialty cut-flower crop sales are likely to expand.

\section{Literature Cited}

Acerno, M.E. 1988. Insect problems in the commercial production of cut and dried flowers. Proc. Commercial Field Prod. Cut and Dried Flowers. Minneapolis. p. 99-108.

Armitage, A.M. 1987. The influence of spacing on field-grown perennial crops. HortScience 22(5):904-907.
Armitage, A.A. 1989. Some minor bulbs for greenhouse or field cut flowers. Proc. 2nd Natl. Conf. Specialty Cut Flowers, Athens, Ga. p. 99101.

Borochov, A. and V. Keren-Paz. 1984. Bud opening of cut liatris flowers. Scientia Hort. 23:85-89.

Bristow, M. (ed.). 1988. Kiplinger agriculture letter. Kiplinger Washington Editors. Washington, D.C. 29 July, p. 3.

Brumfield, R. 1989. Cost of production. Proc. 2nd Natl. Conf. Specialty Cut Flowers, Athens, Ga. p. 17-26.

DeHertogh, A.A. 1989. Dutch iris, Liatris, and lilies as outdoor cut bulb flowers. Proc. 2nd Natl. Conf. Specialty Cut Flowers. Athens. Ga. p. 93-98.

Dirr, M.A. 1989. "Woodies" with cut potential. Proc. 2nd Natl. Conf. Specialty Cut Flowers. Athens, Ga. p. 168-171.

Dufault, R.J., T. Phillips, and J. Kelly. 1990a. Gerbera daisies: A potential field-produced cut flower crop for coastal South Carolina. Proc. 1st New Crop Symp. Timber Press, Portland, Ore. (In press).

Dufault, R.J., T.L. Phillips, and J.W. Kelly. 1990b. Nitrogen and potassium fertility and plant populations influence field production of Gerbera. HortScience 25:1599-1602.

Godwin, B.J. 1988. Grains for the florist trade. Proc. Commercial Field Prod. Cut and Dried Flowers. Minneapolis. p. 77-86.

Gilreath, J.P. 1986. Response of gladiolus, statice, and gypsophila to residues of preemergence herbicides. Proc. Fla. State Hort. Soc. 99:275278.

Kelly, J.W. and T.J. Starman. 1990. Postharvest handling of Physostegia purpurea cut flowers. HortScience 25(5):552-553.

Laurie. A. and V.H. Ries. 1950. Floriculture fundamentals and oractices. 2nd ed. McGraw-Hill, New York.

Lukaszewska, A.J. 1980. Effect of some chemicals on cut dahlia flowers. Acta Hort. 109:241-245.

Meyer, M.H. 1988. Everlasting ornamental grasses. Proc. Commercial Field Prod. Cut and Dried Flowers. Minneapolis. p. 69-76.

Pfleger. F.L. 1988. Diseases of dried flowers in Minnesota. Proc. Commercial Field Prod. Cut and Dried Flowers, Minneapolis. p. 93-98.

Rugen, C. 1989. Integrated pest management. Proc. 2nd Natl. Conf. Specialty Cut Flowers. Athens, Ga. p. 130-144.

Seals, J.L. 1988. Factors in selecting crops for cut flowers. Proc. Commercial Field Prod. Cut and Dried Flowers. Minneapolis. p. 39-56.

Senesac, A.F. 1988. Weed problems in field grown cut flowers. Proc. Commercial Field Prod. Cut and Dried Flowers. Minneapolis. p. 87-92.

Taylor, A.D. 1916. Plants for landscape planting. A.D. Taylor, Cleveland, Ohio.

Tjia, B. 1985. Hybrid calla lilies: A potential new crop for Florida. Proc. Fla. State Hort. Soc. 98:127-130.

U.S. Census Bureau. 1931. U.S. census. 1930. Agriculture. vol. IV Govt. Printing Off. Washington, D.C.

Weiler, C.J. 1988. Wildflowers and weeds. Proc. Commercial Field Prod. Cut and Dried Flowers, Minneapolis. p. 153-158.

White, E.A. 1915. The principles of floriculture. Norwood Press, Norwood, Mass. 